\title{
Study on the Combined-Syllable Words of Xiuwu Dialect
}

\author{
Shanshan Wang \\ School of Humanities, Tiangong University, Tianjin, China \\ Email:472894835@qq.com
}

How to cite this paper: Wang, S.S. (2021) Study on the Combined-Syllable Words of Xiuwu Dialect. Open Access Library Journal, 8: e7577.

https://doi.org/10.4236/oalib.1107577

Received: May 24, 2021

Accepted: June 21, 2021

Published: June 24, 2021

Copyright $\odot 2021$ by author(s) and Open Access Library Inc.

This work is licensed under the Creative Commons Attribution International License (CC BY 4.0).

http://creativecommons.org/licenses/by/4.0/

\begin{abstract}
Xiuwu has a unique regional culture because of its special geographical position, and has formed a unique regional dialect. Through the detailed description of the phenomenon of syllable contraction in Xiuwu dialect, this paper enables people to correctly understand the combined-syllable words in Xiuwu dialect and its important role. Based on the classification criteria of different parts of speech, this paper sorts out the combined-syllable words in Xiuwu dialect, and holds that there are roughly two types of combined-syllabic words: one is owning pronunciation and characters; the other is owning pronunciation without characters.
\end{abstract}

\section{Subject Areas}

Linguistics

\section{Keywords}

Combined-Syllable Word, Xiuwu Dialect, Syllable Contraction, Chinese

\section{Introduction}

Syllable contraction is a common phonetic change in speech flow. It usually refers to two connected monosyllabic or disyllabic words combined into a monosyllabic word, because of the linking between them. It comes from the oral language, and is the result of accumulation and precipitation of long-term oral communication. The syllable contraction is a common phonetic change phenomenon in Chinese language, which has existed since ancient times. For example, the “[tsu] (诸)" in “Zi Zhang wrote it on his belt of official costume (子张书诸 绅)" in the Analects of Confucius-Duke of Wei Ling, it is the combined-syllable word of “[tsi] (之) [jy] (于)”. In this sentence, “[tşu] (诸)” equals to “[tsi] (之) 
[jy] (于)". There also have other examples, like “[xə] (盍)" is the combined-syllable word of “[xə] (何) [pu] (不)", which means "why not" in English; “[pho] (區)" is the combined-syllable word of “[pu] (不) [khə] (可)”, which means impossible in English. The phenomenon of syllable contraction was first explicitly proposed in the Song Dynasty in Shen Kuo's Dream Pool Essays, the writer wrote that "The phenomenon of two words combined into one has existed for a long time, like “[pu] (不) [khə] (可)” combined as “[pho] (區)”, “[xə] (何) [pu] (不)” combined as “[xə] (盍)”, “[zu] (如) [si] (是)” combined as “[ə] (尔)”, “[ə] (而) [i] (已)” combined as “[ə] (耳)”, and “[ $\mathrm{t} \$ \mathrm{i}]$ (之) [xu] (乎)” combined as “[t\$u] (诸)” etc. Nowadays, there are many syllable contractions appearing in daily communication, such as “[pu] (不) [jon] (用)” fats reading as “[pən] (零)”, which means "no needs"; “[ni] (你) [men] (们)" quickly pronounced as “[nən] (恁)", which means “you”; “[t\$̧] (这) [ja门] (样)" pronounced as “[tian] (酱)”, which means "in this way". When speaking too fast, the initial of the first syllable of some disyllabic words happens to form a "Fanqie" (a traditional method of indicating the pronunciation of a Chinese character) with the final of the second syllable. In this way, the disyllabic word becomes a monosyllabic word. Although the proportion of combined-syllable words in Mandarin is small, combined-syllable words exist in a large number of dialects and have obvious local color. This kind of language phenomenon in the language communication with its unique way of reproduction, it owns tenacious vitality and cannot be ignored status.

At present, the main contents of articles on the study of syllable contraction are as follows: 1) The description and explanation of the syllable contraction in single point dialects, which is the most studied among all the papers at present. This kind of study covers almost every dialect area in China, and has accumulated rich materials of combined-syllable words; 2) Investigate the phonetic formation mode of combined-syllable words, and study how it is generated and existed; 3) To investigate the generating mechanism of syllable contraction; 4) Use the concept of syllable contraction to analyze and solve difficult problems in Chinese dialects.

The analysis and research of the combined-syllable words in Xiuwu dialect can help us to understand the internal formation rules and explore the phonetic levels of the combined-syllable words in Xiuwu dialect, so as to provide reference for the future research of the combined-syllable words in Xiuwu dialect.

\section{The Generative Mechanism of Combined-Syllable Words}

The purpose of studying the generating mechanism of syllable contraction is to explain this phenomenon with a unified theory, and to solve the problems under which conditions syllable contraction begin to combine and what kind of words they will eventually synthesize.

At the present time, there are mainly two kinds of researches on the formation mechanism of syllable contraction, one is the generative mechanism based on edge-in association frame. In an article published in 1997, Chung R. [1] proposed 
to use the edge-in association to explain the generation process of syllable contraction, he believed that the generation of syllable contraction was controlled by the sequential action of three programs. When using edge-in association [2], the two ends (initial and final) were connected first, and then the inner side (main vowel) was connected. However, this theory cannot be used to explain the connection between vowels and compound sounds. Xiao et al. [3] developed this theory, but they still found that they could not fully explain all syllable contraction phenomena. The other is to use the theory of characteristic geometry to explain the consonant process. When Wang [4] discussed the "two-in-one" phonetic wordformation method, she used the operation method of combining the feature tree and the maximum syllable module of the characteristic geometry theory to investigate the phenomenon of $\operatorname{Er}$ (儿) suffixation and Zi (子) suffixation in different regions, and revealed the historical evolution track and process of Er (儿) suffixation and $\mathrm{Zi}$ (子) suffixation. It also discusses the forming mechanism and rules of Er (儿) suffixation and Zi (子) suffixation. Later Zhang [5] used the Er (儿) suffixation, Zi (子) suffixation and D suffixation of Henan dialect as the research object, to investigate the speech pattern, formation mechanism, and mutual restriction conditions of the different types of syllable contraction. This study further understands the nature and characteristics of these kinds of syllable contraction and the generation mechanism behind them.

At present, the research on the mechanism of syllable contraction is relatively limited, the proposed theoretical mechanism is not applicable to a wider range of syllable contraction types, and the study of this phenomenon cannot be analyzed from multiple different perspectives. Further observation and testing are needed to study the mechanism of syllable contraction.

\section{Combined-Syllable Words in Xiuwu Dialect}

\subsection{History and Actuality of Xiuwu Dialect}

Xiuwu was called "Ningyi" before the Zhou Dynasty. At the end of the Shang Dynasty, King Wu attacked Zhou. When his army passed through Ningyi, it encountered a rainstorm and stationed troops to practice martial arts, hence its named this place as "Xiuwu". Xiuwu County is located in the northwest of Henan Province, under the jurisdiction of Jiaozuo City. It is adjacent to Huixian County and Huojia County in the east, connected to Boai County and Jiaozuo urban area in the west, and adjacent to Wuzhi County in the south. Xiuwu dialect is belonging a small piece named "Han-xin" of Jin language, located in the border area of the north of Henan Jin language and the Central Plains Mandarin. The internal differences of Xiuwu dialect are not obvious and can be divided into two parts: Chengguan (Chengguan town and suburbs) and Xiangxia (surrounding villages and towns).

\subsection{General Phonology of Xiuwu Dialect}

According to the previous studies, there are 23 initials (include zero-onset, [ø]), 
44 finals (includes one vowel [1], which can make syllable itself), and five tones in Xiuwu dialect. They all listed in following Tables 1-3.

Table 1. Initials in Xiuwu dialect.

\begin{tabular}{|c|c|c|c|c|c|c|c|c|}
\hline \multirow{2}{*}{ Place } & \multicolumn{2}{|c|}{ Stop } & \multicolumn{2}{|c|}{ Fricative } & \multicolumn{2}{|c|}{ Affricate } & \multirow{2}{*}{ Nasal } & \multirow{2}{*}{ Latera } \\
\hline & unasp & asp & voiceless & voiced & unasp & asp & & \\
\hline Bilabial & $\mathrm{p}$ & $\mathrm{p}^{\mathrm{h}}$ & $\mathrm{f}$ & & & & $\mathrm{m}$ & \\
\hline Alveolar & $\mathrm{t}$ & $\mathrm{t}^{\mathrm{h}}$ & $\mathrm{s}$ & & ts & $\mathrm{ts}^{\mathrm{h}}$ & $\mathrm{n}$ & 1 \\
\hline Retroflex & & & $\mathrm{s}$ & z & & & & \\
\hline Dental & & & & & ts & $\mathrm{ts}^{\mathrm{h}}$ & & \\
\hline Palatal & & & 6 & & to & $\mathrm{tc}^{\mathrm{h}}$ & & \\
\hline Velar & $\mathrm{k}$ & $\mathrm{k}^{\mathrm{h}}$ & $\mathrm{x}$ & $y$ & & & & \\
\hline
\end{tabular}

Table 2. Finals in Xiuwu dialect.

\begin{tabular}{|c|c|c|c|}
\hline $\begin{array}{l}\text { Final without } \\
\text { on-glide }\end{array}$ & $\begin{array}{l}\text { Final with } \\
\text { on-glide [j] }\end{array}$ & $\begin{array}{l}\text { Final with } \\
\text { on-glide [w] }\end{array}$ & $\begin{array}{l}\text { Final with } \\
\text { on-glide [y] }\end{array}$ \\
\hline [i] & [i] & {$[\mathrm{u}]$} & [y] \\
\hline [o] & & [uo] & \\
\hline [a] & [ia] & [ua] & \\
\hline [ə] & {$[\mathrm{i} \varepsilon]$} & & [yz] \\
\hline$[\gamma]$ & [ir] & [ur] & {$[y \gamma]$} \\
\hline [ai] & & [uai] & \\
\hline [ei] & & [uei] & \\
\hline$[\mathrm{au}]$ & [iau] & & \\
\hline [ou] & [iou] & & \\
\hline [ən] & [in] & [uən] & [yn] \\
\hline [an] & [ian] & [uan] & \\
\hline [əң] & [iən] & [uon] & [yon] \\
\hline [a?] & [ia?] & [ua?] & [ya?] \\
\hline [ə२] & [iə?] & [นə?] & [уә?] \\
\hline
\end{tabular}

Table 3. Tones in Xiuwu dialect.

\begin{tabular}{cccccc}
\hline & Yin-ping & Yang-ping & Shang-tone & Qu-tone & Ru-tone \\
\hline pitch & 44 & 21 & 52 & 12 & 4 \\
\hline
\end{tabular}




\subsection{Syllable Contraction in Xiuwu Dialect}

There are many combined-syllable words in Xiuwu dialect, and the phenomenon of syllable contraction is common, which greatly enriches the vocabulary of Xiuwu dialect. As a whole, the combined-syllable words in Xiuwu dialect can be divided into two categories: one is combined-syllable words with sound and characters; the other is only owning sounds and without characters. As the result of dialect colloquialism, there are many combined-syllable words with sounds and no characters, and they are mostly used in daily communication. According to its part of speech, the phenomenon of syllable contraction in Xiuwu dialect can be roughly classified into the following categories:

1) Numeral words

$$
\begin{aligned}
& {\left[\mathrm{y}^{44}\right]<\left[\mathrm{i}^{44}\right](一)+\left[\mathrm{k}^{21}\right] \text { (个) }} \\
& {\left[\mathrm{lia}^{52}\right](\text { 俩 })<\left[\mathrm{liah}^{52}\right] \text { (两) }+\left[\mathrm{ke}^{21}\right] \text { (个) }} \\
& {\left[\mathrm{sa}^{44}\right](\text { 仁 })<\left[\mathrm{sr}^{44}\right](\text { 三 })+\left[\mathrm{k}^{21}\right] \text { (个) }} \\
& {\left[\mathrm{si}^{21}\right]<\left[\mathrm{si}^{21}\right](\text { 四 })+\left[\mathrm{k}^{21}\right](\text { 个 })} \\
& {\left[\mathrm{uo}^{52}\right]<\left[\mathrm{u}^{52}\right] \text { (五) }+\left[\mathrm{k}^{21}\right] \text { (个) }} \\
& {\left[\mathrm{luo}^{44}\right]<\left[\mathrm{liu}^{21}\right](\text { 六 })+\left[\mathrm{k}^{21}\right] \text { (个) }} \\
& {\left[\mathrm{tci \varepsilon}^{44}\right]<\left[\mathrm{tci}^{44}\right] \text { (七) }+\left[\mathrm{kg}^{21}\right] \text { (个) }} \\
& {\left[\mathrm{pa}^{44}\right]<\left[\mathrm{po}^{44}\right] \text { (八) }+\left[\mathrm{k}^{21}\right] \text { (个) }} \\
& {\left[\mathrm{tcy} \partial^{21}\right]<\left[\mathrm{tciu}^{12}\right] \text { (九) }+\left[\mathrm{k}^{21}\right] \text { (个) }} \\
& {\left[\mathrm{s}^{12}\right]<\left[\mathrm{s}^{44}\right](十)+\left[\mathrm{k}^{21}\right](\text { 个) }} \\
& {\left[\mathrm{tcir}^{52}\right]<\left[\mathrm{tci}^{52}\right] \text { (几) }+\left[\mathrm{kə}^{21}\right] \text { (个) }}
\end{aligned}
$$

In Xiuwu dialect, there is a sound change when the numeral word and the quantifier "kə (个)" read together, and the combined-syllable word becomes a new syllable. Because they are mostly used in oral communication, most of them have no corresponding words to express.

Among them, [tcir $\left.\gamma^{52}\right]$ is a combination of the numeral "[tci $\left.{ }^{2}\right]$ " and the quantifier " $\left[\mathrm{ke}^{21}\right]$ ", which means "several" in English. With the initial of "[tij $\left.{ }^{2}\right]$ ", finals of $\left[\mathrm{ke}^{21}\right]$ and the medial sound [i] to spell together, then there is a combined-syllable word- $\left[\mathrm{tcir}^{52}\right]$. It can be used to ask about the number of people or things, as in "How many ([66ir $\left.{ }^{52}\right]$ ) apples in the basket?"; It can also be used to refer to a type of person or thing, as in "You([t6ir $\left.\left.{ }^{52}\right]\right)$ can sweep the floor".

2) Pronouns

$$
\begin{aligned}
& \left.\left[\mathrm{saa}^{21}\right] \text { (啥) < [sən }{ }^{21}\right] \text { (什) }+\left[\mathrm{mr}^{21}\right] \text { ( 么) } \\
& {\left[\mathrm{tsa}^{52}\right] \text { (咋) }<\left[\mathrm{tsan}^{21}\right] \text { (怎) }+\left[\mathrm{mr}^{21}\right] \text { (么) }} \\
& {\left[\mathrm{ts}^{2} \mathrm{i}^{21}\right]\left(\text { 镇) }<\left[\mathrm{tgs}^{44}\right](\text { 这 })+\left[\mathrm{mr}^{21}\right](\text { 么 })\right.} \\
& {\left[\mathrm{n}^{\mathrm{i}^{21}}\right](\text { 恁 })<\left[\mathrm{na}^{21}\right] \text { (那) }+\left[\mathrm{mr}^{21}\right](\text { 么) }} \\
& {\left[\mathrm{non}^{53}\right] \text { (恁) }<\left[\mathrm{ni}^{21}\right] \text { (你) }+\left[\mathrm{men}^{44}\right] \text { (们) }} \\
& {\left[\mathrm{tsuo}^{12}\right]<\left[\mathrm{tss}^{44}\right](\text { 这 })+\left[\mathrm{k}^{21}\right] \text { (个) }} \\
& {\left[\mathrm{nuo}^{12}\right]<\left[\mathrm{na}^{21}\right] \text { (那) }+\left[\mathrm{ko}^{21}\right] \text { (个) }} \\
& {\left[\mathrm{tuo}^{12}\right]<\left[\mathrm{tuo}^{44}\right] \text { (多) }+\left[\mathrm{so}^{21}\right] \text { (少) }}
\end{aligned}
$$

Among them, [tuo ${ }^{12}$ ] is a combination of the interrogative pronoun "how many", which is formed by combining the initial $[t]$ of " $\left[\operatorname{tuo}^{44}\right]($ 多)" with the fi- 
nal [o] of “[ $\left[\mathrm{So}^{21}\right]$ (少)" and adding the medial sound [u] in the middle. [nวi $\left.{ }^{21}\right]$ and $\left[n^{n}{ }^{53}\right]$ can both be written as “恁”, but the meaning varies depending on the pitch of the tone.

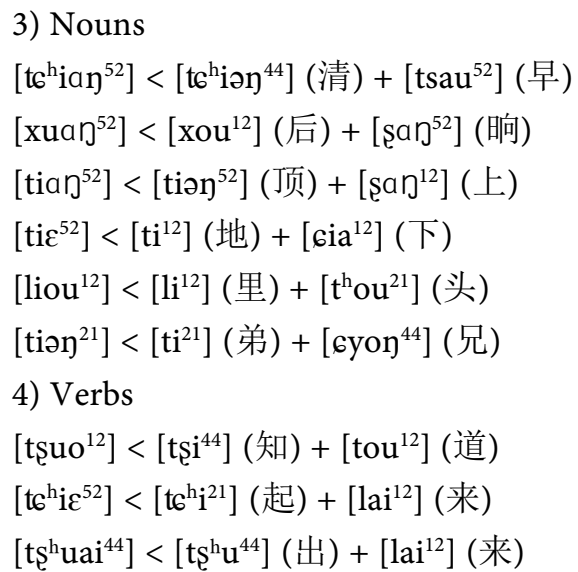

Chinese syllables are composed of three parts: initials, finals and tones, of which initials and finals are segmental components of syllables. We can find the segmental components of the syllable in Xiuwu dialect by observing the characters before and after the syllable in a combined-syllable word and the initials and finals of the syllable. After observation, there are roughly the following three types: 1) Taking the initials of the first syllable and the finals of the last syllable. This is the general form of the combined-syllable word in Xiuwu dialect. By extracting the two parts, a new monosyllable word would be created, like [nən ${ }^{53}$ ] (恁) < $\left[\mathrm{ni}^{21}\right]$ (你) $+\left[\mathrm{men}^{44}\right]$ (们); 2) Taking the whole syllable of the preceding word and the finals of the following word, like $\left[\operatorname{tchi}^{52}\right]<\left[\operatorname{tchi}^{21}\right]$ (起) $+\left[\operatorname{lai}^{12}\right]$ (来), $\left[\operatorname{liou}^{12}\right]<\left[\mathrm{li}^{12}\right]$ (里) $+\left[\mathrm{thou}^{21}\right]$ (头), $\left[\mathrm{ts}^{\mathrm{h}} \mathrm{uai}^{44}\right]<\left[\mathrm{ts}^{\mathrm{h}} \mathrm{u}^{44}\right]$ (出) + [lai $\left.{ }^{12}\right]$ (来); 3) Tak-

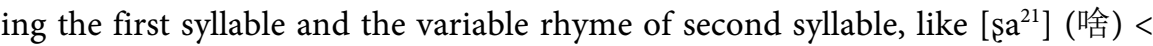
$\left[\mathrm{s}^{21}{ }^{21}\right]($ 什 $)+\left[\mathrm{mr}^{21}\right]\left(\right.$ 么), $\left[\mathrm{nuo}^{12}\right]<\left[\mathrm{na}^{21}\right]$ (那) $+\left[\mathrm{kə}^{21}\right]\left(\right.$ 个), [lia $\left.{ }^{52}\right]($ 俩 $)<\left[\left.\mathrm{lia}\right|^{52}\right]$ (两) $+\left[\mathrm{k} \partial^{21}\right]($ 个) .

\subsection{The Cause of Formation of Combined-Syllable Word in Xiuwu Dialect}

For the phenomenon of syllable contraction in dialects, linguists generally believe that it is the result of speaking too fast. There is a explanation of "[t\$u] (诸)" in a Chinese linguistics book named "Xiao Er Ya", it wrote that, "[t\$su] (诸)" equals to “[t\$̧i] (之) [xu] (乎)". When you speak fast, it is [t\$u] (诸); while it is [tsi] (之) [xu] (乎), when you speak slowly. However, some scholars point out that it is too simple to explain the syllable contraction phenomenon by saying it due to quickly reading, which will conceal the phonetics changes behind the syllable contraction. From the above analysis of the combined-syllable words in Xiuwu dialect, it can be seen that the linking elements of the words are not always combined under the condition of rapid linking, but have certain selectivity. Fast reading can be said to be the direct contributing factor of syllable contraction, but not the basic reason. 
$\mathrm{Xu}$ [6] thought that, structural pattern is the lever that governs the operation and evolution of a language, Chinese syllables are phonetic units representing meanings. Each syllable or one word expresses a conceptual meaning, which makes Chinese present the basic structural pattern of "one word, one syllable, one concept". This is the simplest and most basic principle of the Chinese word construction. Sun [7] further summarized the relationship between syllable and meaning as the law of "one syllable, one meaning". That is to say, "Chinese morphemes are monosyllabic in nature; a morpheme meaning can only be expressed by a syllable, and a syllable must carry a morpheme meaning." "one syllable, one meaning" is the basic reason of syllable contraction. As Chen [8] said, syllable contraction actually reflects Chinese's pursuit of monosyllabic, that is, "single" or "one". "The fundamental spirit is to make '2' or 'many' syllables obey the requirement of ' 1 ' in 'one concept', and integrate them into one from the perspective of phonetic".

\section{Conclusions}

There have two principles which must be followed during the process of language development: one is the principle of least effort; the other is to distinguish meaning. Combined-syllable words are words that combine two or several connected monosyllabic words into one syllable in speech flow, which is the embodiment of the principle of least effort. Moreover, most of the combined-syllable words have pronunciation but no characters, therefore those words have the function of distinguishing meanings. The existence of a large number of combined-syllabic words in Xiuwu dialect plays an important role in enriching the expressive force of the language. In Xiuwu dialect, there are roughly two types of combined-syllabic words: one is owning pronunciation and characters; the other is owning pronunciation without characters. In order to promote the healthy development of Chinese, we should pay more attention to the study of combined-syllable words.

Xiuwu has a unique regional culture because of its special geographical position, and has formed a unique regional dialect. The combined-syllable words in Xiuwu dialect are an important part, and the study of combined-syllable words in Xiuwu dialect is more helpful to understand the whole picture of Xiuwu dialect and to enrich the understanding of Xiuwu dialect. The development and changes of the combined-syllable words themselves have also raised many questions worth exploring for language researchers.

\section{Conflicts of Interest}

The author declares no conflicts of interest regarding the publication of this paper.

\section{References}

[1] Chung, R. (1997) Syllable Contraction in Chinese. Chinese Languages and Linguis- 
tics III: Morphology and Lexicon (Ed. by Tsao, F.F. and Wang, H.S.). Institute of History and Philology, Academia Sinica, Taipei, 199-235.

[2] Yip, M. (1988) Template Morphology and the Directionality of Association. Natural Language and Linguistic Theory, 6, 551-577. https://doi.org/10.1007/BF00134493

[3] 萧宇超. 从台语音节连并到音韵、构词与语法的关系: 老问题、新角度 [G]. 中 国境内语言暨语言学: 第 5 辑. 台北: 中央研究院语言学研究所筹备处, 1999: 251-288.

[4] 王洪君. 汉语非线性音系学: 增订版[M]. 北京: 北京大学出版社, 2008: 200-221.

[5] 张慧丽. 汉语方言变韵的语音格局[D]: [博士学位论文]. 北京: 北京大学, 2011.

[6] 徐通铭. 音节的音义关联和汉语的变音[J]. 语文研究, 2003(3): 1-8.

[7] 孙景涛. 论“一音一义”[G]. 语言学论丛: 第 31 辑. 北京: 商务印书馆, 2005: 48-71.

[8] 陈卫恒. 音节与意义暨音系与词汇化、语法化、主观化的关联: 豫北方言变音的 理论研究 $[\mathrm{M}]$. 北京: 北京语言大学出版社, 2011. 